УДК 582.912.42:58.084.1+58.085.2

\title{
In vitro establishment and TDZ-induced regeneration from shoot and leaf explants of Rhododendron sichotense Pojark.
}

\author{
Yu. G. Zaytseva ${ }^{1 *}$, M. V. Skaptsov², M. G. Kutsev³ ${ }^{3}$ T. I. Novikova ${ }^{1}$ \\ ${ }^{1}$ Central Siberian Botanical Garden, Solotodolinskaya st., 101, Novosibirsk, 630090, Russian Federation. \\ E-mail: ulianna_zaitseva@mail.ru* \\ ${ }_{2}^{2}$ Altai State University, Lenina pr., 61, Barnaul, 656049, Russian Federation.E-mail:mr.skaptsov@mail.ru \\ ${ }^{3}$ Institute of Fundamental Biology and Biotechnology, Siberian Federal University, 79, Svobodnyi pr., Krasnoyarsk, \\ 660041,Russian Federation.E-mail:m_kucev@mail.ru \\ * Corresponding author
}

Keywords: adventitious shoot regeneration, axillary shoot proliferation, Rhododendron sichotense, thidiazuron.

Summary. Rhododendron sichotense Pojark. (Ericaceae) is a winter-hardy species native to the Russian Far East, highly valued as an attractive ornamental woody plant. In order to establish of in vitro culture without the problem with exudation of polyphenols and to induce multiplication from leave and shoot explants of field grown plants, the procedure including the pre-cultivation of explants on hormone free Anderson Medium (AM0) for 3 days followed by cultivation on AM supplemented with varying thidiazuron (TDZ) concentrations $(0.1,0.5,1.0 \mu \mathrm{M})$ was developed. The elongation on hormone-free AM0 allowed obtaining the healthy shoots without any anomalies. The best response in terms of the regeneration frequency $(50 \%)$, the shoot number per explant $(41.60 \pm 5.25)$ and the shoot length $(12.20$ $\pm 1.04 \mathrm{~mm}$ ) was achieved under $0.5 \mu \mathrm{M}$ of TDZ from leaf explants.

\section{Введение в культуру in vitro и ТДЗ-индуцированная регенерация Rhododendron sichotense Pojark. из листовых и побеговых эксплантов}

\author{
Ю. Г. Зайцева ${ }^{1 *}$ М. В. Скапцов², М. Г. Куцев ${ }^{3}$, Т. И. Новикова ${ }^{1}$ \\ ${ }^{1}$ Центральный сибирский ботанический сад СО РАН, ул. Золотодолинская, д. 101, г. Новосибирск, 630090, Россия \\ ${ }_{2}^{2}$ Алтайский государственный университет, пр. Ленина, 61, г. Барнаул, 656049, Россия \\ ${ }^{3}$ Институт фундаментальной биологии и биотехнологии, Сибирский федеральный университет, \\ Свободный пр. 79, г. Красноярск, 660041, Россия
}

\begin{abstract}
Ключевые слова: пролиферация пазушных побегов, регенерация адвентивных побегов, тидиазурон, Rhododendron sichotense.

Аннотация. Rhododendron sichotense Pojark. (Ericaceae) является высокоценным декоративным древесным зимостойким видом природной флоры российского Дальнего Востока. Разработана методика введения в культуру in vitro, позволяющая предотвратить негативный эффект фенольного окисления. Экспланты, листья и части побегов изолировали от растений открытого грунта и предкультивировали на безгормональной среде Андерсона (AМ0) в течение трех дней, с последующим переносом на среду того же минерального состава, дополненную тидиазуроном в различных концентрациях $(0,1 ; 0,5 ; 1,0$ мкM). Элонгация на AM0 позволила получить здоровые побеги без аномалий развития. Наилучший ответ по частоте регенерации (50 \%), количеству побегов на эксплант $(41,60 \pm 5,25)$ и длине побегов $(12,20 \pm 1,04$ мм) получен из листовых эксплантов под действием 0,5 мкМ ТДЗ.
\end{abstract}




\section{Introduction}

Rhododendron sichotense Pojark. is a highly ornamental, winter hardy, semi-evergreen shrub native to the Sikhote-Alin Mountains of the Russian Far East. This species possesses a corolla-color variability (pink, white, cream-colored, dark purple) and different terms of blooming (Vrishch et al., 2010), which make $R$. sichotense one of the most promising wild-growing species for breeding and landscaping. Moreover, the wide range of phenolic compounds containing in aboveground organs of $R$. sichotense provides it with medicinal value (Karpova, Karakulov, 2013). Due to existing difficulties to propagate rhododendrons using conventional methods, the biotechnological approaches are the most often applied for developing the efficient systems for the large-scale plant production (Eeckhaut et al., 2010). A key to success in the establishment of tissue culture protocol is the choice of plant growth regulators. Up to date, there have been many reports on the clonal micropropagation of evergreen rhododendrons using 2-isopentenyladenine (2-iP) as cytokinin (Eeckhaut et al., 2010), whereas for some species, the application of zeatin is preferable (Almeida et al., 2005; Zaytseva et al., 2018). However, none of these studies is devoted to in vitro establishment and micropropagation of $R$. sichotense from the natural population using leave and shoot explants.

The most powerful trigger for morphogenesis in tissue culture of woody plants is a synthetic cytokinin thidiazuron (TDZ), a substituted phenylurea compound, which, depending on the concentration and the type of explant, can initiate a wide range of morphogenic reactions (Murthy et al., 1998; Novikova, Zaytseva, 2018). TDZ is known to induce the higher regeneration rates in the comparison to purine-based cytokinins and also demonstrates the ability of fulfilling both the cytokinin and auxin requirements of regeneration responses in a number of woody plants (Jones et al., 2007). However, unfavorable side effects of TDZ have been reported including morphological abnormalities (i. e., fasciated shoots, hyperhydricity, inhibited shoot elongation) and difficulties in rooting and ex vitro acclimatization. The undesirable effects associated with applying TDZ can be overcome by reducing TDZ concentrations and exposure time (Dewir et al., 2018; Novikova, Zaytseva, 2018). At the same time, the establishment of in vitro culture of wild-growing rhododendrons is difficult due to the high content of phenolic compounds in explants (Vasilieva, 2009). The accumulation and subsequent oxidation of phenolic compounds result in reduced growth, lower rates of regeneration or recalcitrance and can ultimately lead to explant necrosis (Uchendu et al., 2011). Therefore, the establishment of rhododendron explants from field conditions requires the special procedures to escape the problem associated with exudation of polyphenol compounds from cut surface.

The present study aimed to establish an efficient protocol of in vitro multiplication for $R$. sichotense from shoot tips and young leaves using TDZ to induce direct shoot regeneration without developmental abnormalities.

\section{Materials}

\section{Objects}

1. Fresh first pairs of $R$. sichotense leaves with petioles (from field plants).

2. Fresh juvenile shoots consisted of 3 nodes with apical buds (from field plants).

\section{Reagents}

1. Ethanol (70 \% $[\mathrm{v} / \mathrm{v}]$ in distilled water).

2. $0.05 \%$ Sodium hypochlorite $(20 \%$ Domestos Unilever, Russia $[\mathrm{v} / \mathrm{v}]$ in distilled water).

3. Macro- and microelements as well as adenine sulfate and vitamins according to Anderson's medium prescription (Anderson, 1984).

4. Bacto agar (PanReac, Barcelona, Spain).

5. Sucrose (Shostka Chemical Reagent Factory, Shostka, Ukraine).

6. Thidiazuron (BioReagent, SigmaAldrich, USA).

\section{Equipment}

1. Micropipetters, 10-, 100-, 1000- $\mu 1$ with corresponding tips.

2. Culture jars of $100 \mathrm{~mL}$.

3. Cool white fluorescent light (Philips, Pila, Poland).

4. Orbital shaker (Elmi, S-3-02L, Latvia).

\section{Procedures}

\section{Culture Media and Conditions}

1. $0.6 \%(\mathrm{w} / \mathrm{v})$ agar-solidified Anderson's medium (AM) supplemented with $3 \%$ sucrose (w/v) was used in all experiments.

2. The $\mathrm{pH}$ of the medium was adjusted to 5.0 before autoclaving $\left(121^{\circ} \mathrm{C} ; 1.05 \mathrm{~kg} \mathrm{~cm}-2\right)$.

3. Plant growth regulators (PGRs) were added post-autoclaving. 
4. Cultures were maintained under cool white fluorescent light (Philips, Poland) at the intensity of $40 \mu \mathrm{mol} \mathrm{m}-2 \mathrm{~s}-1$ with a $16-\mathrm{h}$ photoperiod and $23 \pm 2{ }^{\circ} \mathrm{C}$.

\section{Sterilization}

1. Leaves and shoots were soaked in $70 \%$ ethanol for 2 min.

2. Leaves and shoots were transferred to $0.05 \%$ sodium hypochlorite solution and placed on an orbital shaker at 90 revolutions per min. for $20 \mathrm{~min}$.

3. A sterilized plant material was washed in sterile distilled water three times.

\section{Explant preparation}

1. To obtain shoots explants, all leaves were removed from the sterilized shoots.
2. To obtain leaf explants, the leaves with petioles were cut into two parts near the middle of lamina across the main vein. To induce morphogenesis, the parts of leaves with petioles were used.

\section{Shoot induction from shoot explants}

1. Shoot explants were inoculated horizontally on hormone-free AM (AM0) for 3 days (pre-cultivation step).

2. After pre-cultivation the explants were transferred to AM supplemented with 0.1, 0.5, $1.0 \mu \mathrm{M}$ of TDZ for 8 weeks (multiplication step).

3. After 8 weeks of cultivation, the frequency and the type of morphogenic response, the number of axillary shoots per explant (with length more than $5 \mathrm{~mm}$ ) and the shoot length were examined (Table, Fig.1).

Table

Effect of TDZ on shoot regeneration from Rhododendron sichotense shoot and leaf explants.

Means followed by the same letter are not significantly different according to Duncan test $(\mathrm{P}>0.05)$.

\section{Means \pm SE}

\begin{tabular}{|c|c|c|c|c|}
\hline Type of explant & $\begin{array}{c}\text { TDZ concentration, } \\
\mu \mathrm{M}\end{array}$ & $\begin{array}{c}\text { Regeneration } \\
\text { frequency, } \%\end{array}$ & $\begin{array}{c}\text { Shoot number per } \\
\text { explant }\end{array}$ & Shoot length, mm \\
\hline \multirow{3}{*}{ Shoot } & 0.1 & 100 & $9.80 \pm 1.83 \mathrm{a}$ & $8.54 \pm 0.48 \mathrm{a}$ \\
\cline { 2 - 5 } & 0.5 & 100 & $7.80 \pm 0.58 \mathrm{a}$ & $6.72 \pm 0.41 \mathrm{~b}$ \\
\cline { 2 - 5 } & 1.0 & 60 & $7.00 \pm 0.97 \mathrm{a}$ & $6.13 \pm 0.61 \mathrm{~b}$ \\
\hline \multirow{3}{*}{ Leaf } & 0.1 & 0 & - & - \\
\cline { 2 - 5 } & 0.5 & 50 & $41.60 \pm 5.25 \mathrm{a}$ & $12.20 \pm 1.04 \mathrm{a}$ \\
\cline { 2 - 5 } & 1.0 & 20 & $32.50 \pm 8.30 \mathrm{a}$ & $9.50 \pm 1.65 \mathrm{a}$ \\
\hline
\end{tabular}
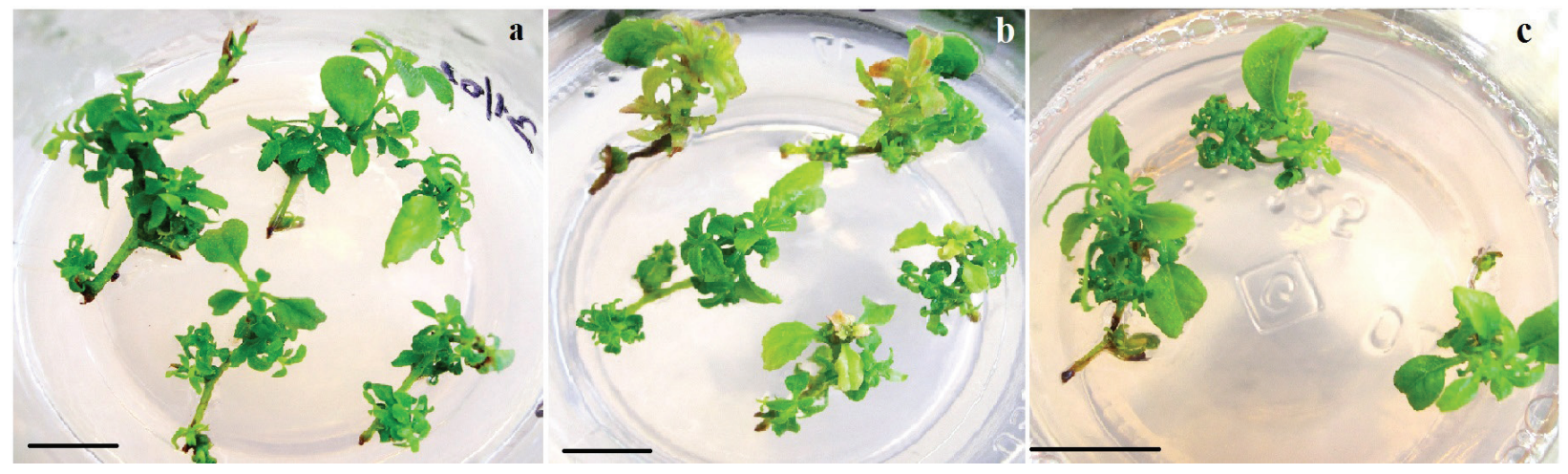

Fig. 1. Axillary shoot proliferation from sterile fresh juvenile shoot explants of Rhododendron sichotense induced by 0.1 (a), 0.5 (b) and 1.0 (c) $\mu \mathrm{M}$ TDZ. Bar $-10 \mathrm{~mm}$.

Shoot induction from leaf explants

1. Leaf explants were placed adaxial side up on the surface of AM0 for 3 days (pre-cultivation step)

2. Explants were transferred to AM supplemented with $0.1,0.5,1.0 \mu \mathrm{M}$ of TDZ for 8 weeks (multiplication step).

3. After 8 weeks of cultivation, the frequency and the type of morphogenic response were analyzed.
4. To overcome TDZ-induced abnormities, the regenerants from leaf explants were cultivated on AM0 for 8 weeks (elongation step).

5. After elongation, the number of adventitious shoots per explant (with length more than $5 \mathrm{~mm}$ ) and the shoot length were determined (Table, Fig. 2). 


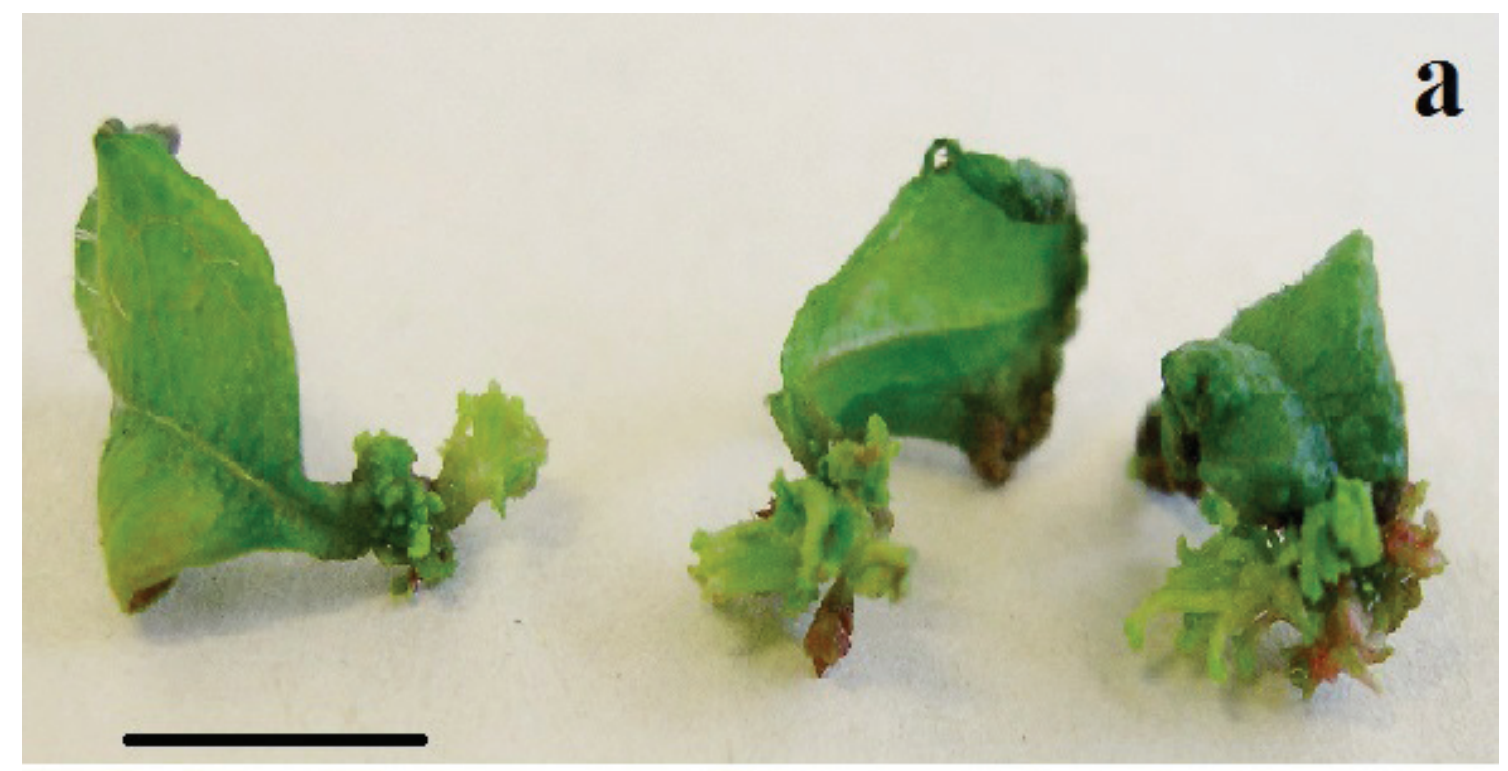

\section{b}
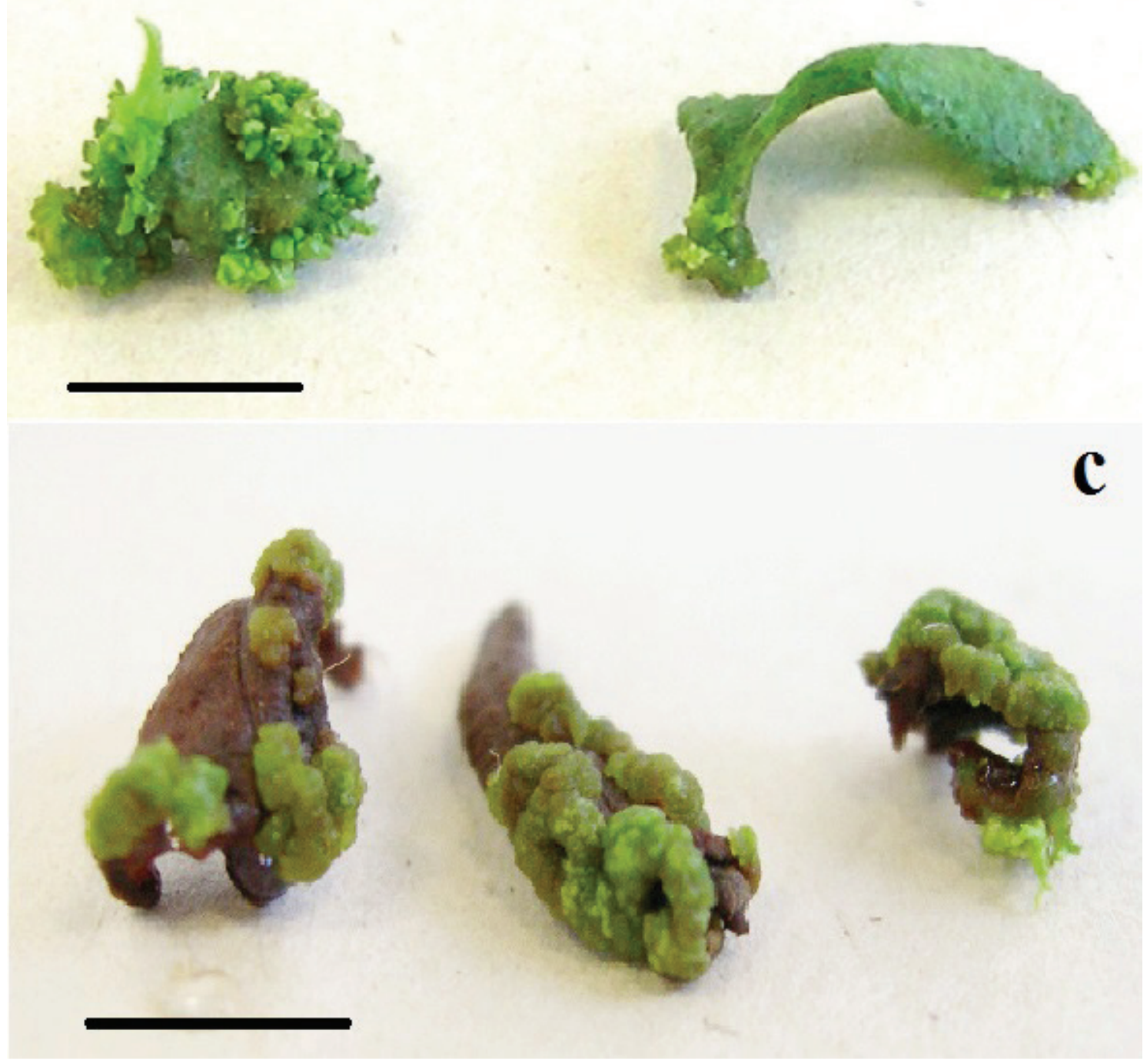

Fig. 2. Adventitious shoot proliferation from sterile fresh leaf explants of Rhododendron sichotense induced by 0.1 (a), 0.5 (b) and 1.0 (c) $\mu \mathrm{M}$ TDZ. Bar $-10 \mathrm{~mm}$. 


\section{Statistical analysis}

1. Fifteen explants were used per treatment in each experiment replicated three times.

2. Data was analyzed by one-way ANOVA using STATISTICA 8 (StatSoft Inc., OK) and presented as means $\pm \mathrm{SE}$ (standard error).

3. Significance between means was tested by Duncan's test $(\mathrm{P}=0.05)$.

\section{Conclusion}

In vitro establishment and initiation of regeneration are the most crucial stages in clonal micropropagation of rhododendrons. Here, we demonstrate an effective protocol for in vitro establishment and micropropagation of $R$. sichotense through activation the axillary bud proliferation from shoot explants as well as de novo direct adventitious shoot regeneration from leaf explants of field plants. To in vitro establish, all tested explants were pre-cultivated for 3 days on AM0 to minimize the negative effects of cutting due to phenolic exudation and drawback of TDZ treatment. The pre-cultivation step enhances the capability for regeneration due to opening the "window of competence" to morphogenesis in plant tissues (Woo, Wetzstein, 2008). This approach has been successfully used for inducing direct shoot regeneration from floral explants of $R$. sichotense (Zaytseva, Novikova, 2017). Depending on the con- centration, TDZ is known to induce the wide range of morphogenic pathways from callus formation to the shoot production and somatic embryogenesis (Murthy et al., 1998). In the present study, the same TDZ concentrations were found to be useful for initiating both the axillary and adventitious shoot production. The elongation on hormone-free AM0 allowed obtaining the healthy shoots without any anomalies. The shoot explants demonstrated the highest regenerate frequency $(60-100 \%)$, however the leaf explants produced the maximum shoot number per explant (up to $41.60 \pm 5.25$ ) and the shoot length $(12.20 \pm 1.04 \mathrm{sm})$ (Table). Consequently, the regeneration system of $R$. sichotense based on direct morphogenesis from leaf explants is found to be more effective for the large-scale plant production.

\section{Acknowledgments}

The work was carried out within the framework of the state task of the Central Siberian Botanical Garden SB RAS № AAAA-A17-117012610051-5 on the project "Assessment of the morphogenetic potential of plant populations in North Asia by experimental methods" and of the state task of the Altai State University project № FZMW-2020-003. In our study, the material from the collection of the Central Siberian Botanical Garden SB RAS USU 440534 "Collection of living plants indoors and outdoors" was used.

\section{REFERENCES / ЛИТЕРАTУРA}

Almeida R., Goncalves S., Romano A. 2005. In vitro micropropagation of endangered Rhododendron ponticum L. subsp. baeticum (Boissier and Reuter) Handel-Mazzetti. Biodiver. Conserv. 14: 1059-1069. DOI: 10.1007/s 10531004-8413-3

Anderson W. C. 1984. A revised tissue culture medium for shoot multiplication of rhododendron. The Journal of the American Society for Horticultural Science 109: 343-347.

Dewir Y., Nurmansyah N., Teixeira da Silva J. 2018. Thidiazuron-induced abnormalities in plant tissue cultures. Plant Cell Rep. 37: 1451-1470. DOI: 10.1007/s00299-018-2326-1

Eeckhaut T., Janssens K., Keyser E., Riek J. 2010. Micropropagation of Rhododendron. In: Protocols for in vitro propagation of ornamental plants: Methods in molecular biology. Eds. S. Jain, S. Ochatt. New York: Humana Press. Pp. 141-152. DOI: 10.1007/978-1-60327-114-1_14

Jones M., Yi Z., Murch S., Saxena P. K. 2007. Thidiazuron-induced regeneration of Echinacea purpurea L.: micropropagation in solid and liquid culture systems. Plant Cell Rep. 26: 13-19. DOI: 10.1007/s00299-006-0209-3

Karpova E. A., Karakulov A. V. 2013. Flavonoids of some Rhododendron species of flora of Siberia and the Russian Far East. The Chemistry of Plant Raw Materials 2: 119-126. [In Russian] (Карпова Е. А., Каракулов А. В. Флавоноиды некоторых видов рода Rhododendron L. флоры Сибири и Дальнего Востока // Химия растительного сырья, 2013. № 2. С 119-126).

Murthy B., Murch S., Saxena P. 1998. Thidiazuron: a potent regulator of in vitro plant morphogenesis. In Vitro Cellular \& Developmental Biology - Plant 34: 267-275. DOI: 10.1007/BF02822732

Novikova T. I., Asbaganov S. V., Ambros E. V., Zaytseva Y. G. 2020. TDZ-induced axillary shoot proliferation of Rhododendron mucronulatum Turcz. and assessment of clonal fidelity using DNA-based markers and flow cytometry. In Vitro Cellular \& Developmental Biology - Plant 56: 307-317. DOI: 10.1007/s11627-019-10049-9 
Novikova T. I., Zaytseva Y. G. 2018. TDZ-induced morphogenesis pathways in woody plant culture. In: Thidiazuron: From Urea Derivative to Plant Growth Regulator. Eds. N. Ahmad, M. Faisal. Singapore: Springer Nature. Pp. 61-94. DOI: 10.1007/978-981-10-8004-3_3

Uchendu E., Paliyath G., Brown D., Saxena P. 2011. In vitro propagation of North American ginseng (Panax quinquefolius p. L.). In Vitro Cellular \& Developmental Biology - Plant 47: 710-718. DOI: 10.1007/s11627-0119379-y

Vasilieva O. V. 2009. Bio-morphological bases of clonal micropropagation of some presentatives of Rhododendron L. genus: Abstract of the thesis of candidate of biological sciences. Moscow. 20 pp. [In Russian] (Василье$\boldsymbol{в} \boldsymbol{a} \boldsymbol{O} \boldsymbol{B} \boldsymbol{B}$. Биолого-морфологические основы клонального микроразмножения некоторых представителей рода Rhododendron L.: Автореф. дис. ... канд. биол. наук. М., 2009. 20 с.).

Vrishch D. L., Varchenko L. I., Urusov V. M. 2010. Rhododendron L. genus on Sikhote-Alin: geography, ecology, genesis, economic prospects. Vestnik Krasnoyarsk State Agrarian University 10: 64-71. [In Russian] (Bpum, Д. Л., Варченко Л. И., Урусов В. М. Род рододендрон (Rhododendron L.) на Сихотэ-Алине: география, экология, генезис, хозяйственные перспективы // Вестник КрасГАУ, 2010. Т. 10. С. 64-71).

Woo S., Wetzstein H. 2008. Morphological and histological evaluations of in vitro regeneration in Elliottia racemosa leaf explants induced on media with thidiazuron. The Journal of the American Society for Horticultural Science 133: $167-172$.

Zaytseva Y. G., Novikova T. I. 2017. In vitro propagation of some frost-resistant genotypes of genus Rhododendron. Plant Life of Asian Russia 4(28): 66-72. [In Russian] (Зайщева Ю. Г., Новикова Т. И. Размножение в культуре in vitro некоторых морозоустойчивых представителей рода Rhododendron // Растительный мир Азиатской России, 2017. № 4(28). С. 66-72). DOI: 10.21782?RMAR1995-2449-2017-4(66-72)

Zaytseva Y. G., Novikova T. I. 2018. Morpho-histological analysis of shoot regeneration and large-scale propagation of an endangered species Rhododendron mucronulatum Turcz. Sib. J. For. Sci. 4: 20-28. DOI: 10.15372/ SJFS20180403 